\title{
Interaction of insulin-like growth factor (IGF)-I and -II with IGF binding protein-2: mapping the binding surfaces by nuclear magnetic resonance
}

\author{
F E Carrick, M G Hinds ${ }^{1,2}$, K A McNeil, J C Wallace, B E Forbes and R S Norton ${ }^{1,2}$ \\ School of Molecular and Biomedical Science, University of Adelaide, 5005, Australia \\ ${ }^{1}$ Biomolecular Research Institute, Parkville 3052, Australia \\ ${ }^{2}$ Walter and Eliza Hall Institute of Medical Research, Parkville 3052, Australia \\ (Requests for offprints should be addressed to R S Norton, Walter and Eliza Hall Institute of Medical Research, 1 G Royal Parade, Parkville 3050 , Australia; \\ Email: Ray.Norton@wehi.edu.au) \\ (F E Carrick is currently at Imclone, New York, USA)
}

\begin{abstract}
The interaction of IGF binding protein-2 (IGFBP-2) with IGF-I and -II has been investigated in solution using nuclear magnetic resonance (NMR) spectroscopy. Chemical shift perturbations in ${ }^{15} \mathrm{~N}$ - and ${ }^{2} \mathrm{H} /{ }^{15} \mathrm{~N}$-labelled IGF-I or $-\mathrm{Il}$ upon binding to unlabelled thioredoxin-tagged bovine IGFBP-2 (Trx ${ }^{1-279}$ GFBP-2) have been monitored to identify residues involved directly in the binding interaction as well as any affected by conformational changes associated with the interaction. A key step in obtaining high-quality spectra of the complexes was the use of transverse relaxation optimised spectroscopy (TROSY) methods with partially deuterated ligands. Indeed, because the effects of conformational averaging and aggregation are eliminated in IGF-I and -II bound to IGFBP-2, the spectra of the complexes are actually superior to those of the free ligands. Comparison of our results with the crystal structure of the complex between IGF-I and an N-terminal fragment of IGFBP-5 allowed identification of those residues perturbed by the C-domain of IGFBP-2. Other perturbations, such as those of Gly ${ }^{19}$ and Asp ${ }^{20}$ of IGF-I (and the corresponding residues in IGF-II) - which are located in a reverse turn linking N-domain and C-domain interactive surfaces - are due to local conformational changes in the IGF-I and -II. Our results confirm that the C-domain of IGFBP-2 plays a key role in binding regions of IGF-I and -II that are also involved in binding to the type-1 IGF receptor and thereby blocking ligand binding to this receptor.
\end{abstract}

Journal of Molecular Endocrinology (2005) 34, 685-698

\section{Introduction}

Insulin-like growth factor binding proteins (IGFBPs) have diverse biological functions, including increasing the circulating half-life of IGFs, delivery of IGFs to target tissues and modulation of IGF interaction with receptors (Clemmons 2001, Firth \& Baxter 2002). IGF bound to IGFBPs is unable to interact with and activate the type-1 receptor (IGF-1R; Bach et al. 1994). Essentially all $(99 \%)$ of the IGFs in the circulation or the extracellular space are associated with one of six IGFBPs (IGFBP-1 to -6) (Frystyk 2004). However, IGF release from the complex by proteolysis of IGFBPs or their interaction with the extracellular matrix leads to increased availability of IGF to bind to the IGF-1R. IGF activation of the IGF-1R results in cell proliferation, differentiation and survival. These properties are central to the role of IGF-I in disease states including cancer and acromegaly (Denley et al. 2003, Paisley \& Trainer 2003, Pollak et al. 2004).
Given the diverse biological effects of IGFs and the central role of IGFBPs in the regulation of IGF activity, the molecular interactions between the IGFs and IGFBPs are of particular interest. High-resolution solution structures have been determined for both IGF-I (Cooke et al. 1991, Sato et al. 1992) and IGF-II (Terasawa et al. 1994, Torres et al. 1995), but not for the IGFBPs. IGF residues involved in binding IGFBPs have been identified using a range of techniques, including residue or domain swapping with insulin and amino acid deletions or mutations (reviewed by Carrick et al. 2002). Analogue studies have shown the importance of the Band A-domains of the IGFs (Fig. 1) in IGFBP binding. Swapping the B-domain of IGF-I for the corresponding insulin B-domain conferred IGFBP binding ability on insulin (De Vroede et al. 1985), and replacement of the IGF-I B-domain with the insulin B-domain reduced serum IGFBP binding (Bayne et al. 1988). $\mathrm{Glu}^{3}$ of IGF-I was shown by site-directed mutagenesis and deletion analyses to contribute to the IGFBP interaction 


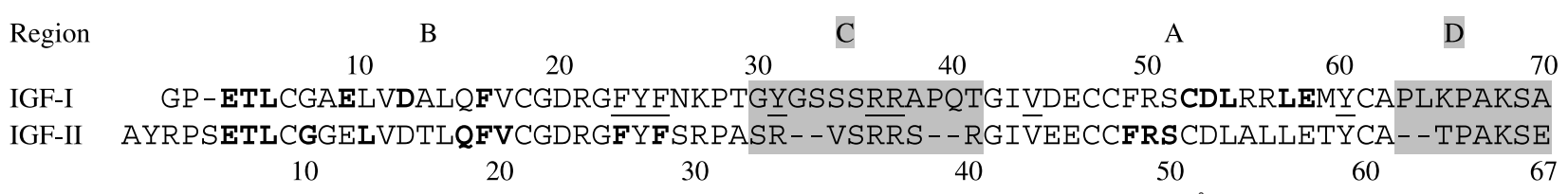

Figure 1 Amino acid sequences of human IGF-I and -II. In the sequence of IGF-I, residues within $4 \AA$ of mini-BP-5 (Zesławski et al. 2001) are highlighted in bold and those shown to be important for IGF-I receptor binding (Cascieri et al. 1988, Bayne et al. 1990, Sakano et al. 1991, Perdue et al. 1994, Jansson et al. 1998, Sato et al. 2000) are underlined. In the sequence of IGF-II, residues shown by mutational studies to be involved in IGFBP binding by IGF-I and/or IGF-II are highlighted in bold (Clemmons et al. 1992, Luthi et al. 1992, Bach et al. 1993, Francis et al. 1993, Jansson et al. 1998, Dubaquie \& Lowman 1999, Sato et al. 2000). Residues in the $C$ and $D$ regions of the IGFs are shaded.

(Bagley et al. 1989), as does the corresponding residue in IGF-II, Glu ${ }^{6}$ (Francis et al. 1993). IGF-I B-domain residues $\operatorname{Gln}^{15}$ and $\mathrm{Phe}^{16}$ are also important, with their mutation, in combination with $\mathrm{Glu}^{3}$ and $\mathrm{Thr}^{4}$ to the corresponding insulin residues, decreasing binding to serum IGFBP by up to 600-fold (Bayne et al. 1988). Alanine scanning mutagenesis across the entire IGF-I molecule identified B-domain residues $\mathrm{Gly}^{7}$, $\mathrm{Leu}^{10}$ and Phe $^{25}$ as important for IGFBP-1 interaction (Dubaquie \& Lowman 1999). Mutagenesis of $\mathrm{Phe}^{26}$ in IGF-II to either Ser or Leu also affected binding to IGFBPs (Bach et al. 1993) as well as the IGF-1R and insulin receptors (Sakano et al. 1991).

A-domain residues $\mathrm{Phe}^{49}, \mathrm{Arg}^{50}$ and $\mathrm{Ser}^{51}$ of IGF-I (Clemmons et al. 1992, Oh et al. 1993) and $\mathrm{Phe}^{48}, \mathrm{Arg}^{49}$ and $\mathrm{Ser}^{50}$ of IGF-II (Bach et al. 1993) are also important for IGFBP interactions. Alanine substitution of IGF-I A-domain residues $\mathrm{Ile}^{43}, \mathrm{Val}^{44}$ or $\mathrm{Leu}^{54}$ reduced binding to IGFBP-1 by 2- to 4-fold, but had a negligible effect on IGFBP-3 binding (Dubaquie \& Lowman 1999). Indeed, different IGF analogues affect binding to each IGFBP family member to varying degrees (Clemmons et al. 1992, Bach et al. 1993, Magee et al. 1999).

The three-dimensional structures of full-length IGFBPs have not yet been determined. The only structural information available until recently has been for residues 40-92 of the N-domain of IGFBP-5, alone (Kalus et al. 1998) and in complex with IGF-I (Zesławski et al. 2001). This region, designated mini-IGFBP-5, binds IGF-I and -II with respectively 10 -fold and 80 -fold lower affinity than full-length IGFBP-5 (Kalus et al. 1998). It contains a hydrophobic IGF binding site, with six of the 12 mini-IGFBP-5 residues within $4 \AA$ of IGF-I being hydrophobic, as well as four of the 12 IGF-I residues within $4 \AA$ of mini-IGFBP-5 (Zesławski et al. 2001) (Fig. 1). We have recently determined the solution structure of the C-domain of IGFBP-6 (Headey et al. 2004a) and mapped the binding site for this C-domain on IGF-II using NMR (Headey et al. 2004b). The IGFBP-6 C-domain has a flat, disc-like structure and its binding to IGF-II perturbs a large number of residues on the surface of IGF-II. This surface lies adjacent to and between the binding sites for the IGFBP N-domain and IGF-I receptor, which have previously been found on opposite sides of the IGF molecule. The C-domain is therefore likely to interfere with IGF binding to the IGF-I receptor, providing a structural basis for the potent inhibitory effects of intact IGFBPs on IGF actions (Headey et al. 2004b).

Despite this progress, we still do not have a clear picture of the interactions of a full-length IGFBP with either of the IGFs. Several years ago, NMR was used to investigate the IGFBP-1 binding surface of IGF-I (Jansson et al. 1998). Perturbed residues on IGF-I included $\mathrm{Pro}^{2}, \mathrm{Glu}^{3}, \mathrm{Cys}^{6}, \mathrm{Gly}^{7}$, Gly ${ }^{19}, \mathrm{Pro}^{28}-\mathrm{Gly}^{30}$, $\mathrm{Gly}^{32}, \mathrm{Arg}^{36}, \mathrm{Arg}^{37}, \mathrm{Gln}^{40}-\mathrm{Gly}^{42}, \mathrm{Pro}^{63}, \mathrm{Lys}^{65}$, Pro $^{66}$ and Lys ${ }^{68}-\mathrm{Ala}^{70}$ (Jansson et al. 1998). The contributions of the Arg residues in IGF-I to IGFBP-1 and IGF-I receptor binding were probed by Ala substitutions, which showed that $\mathrm{Arg}^{50}$ was important for interaction with IGFBP-1 (Jansson et al. 1998). However, the IGF-I ${ }^{15} \mathrm{~N}$ and ${ }^{1} \mathrm{H}$ chemical shift perturbations found in that study were very small (for example, most $\mathrm{NH}$ chemical shifts changed by $\leq 0 \cdot 1$ p.p.m.), with the largest shift being seen for $\mathrm{Ala}^{70}$ which is almost certainly not part of the IGFBP-1 binding surface. By contrast, some NH shift perturbations of mini-BP-5 upon IGF-II binding were as large as 2 p.p.m. (Kalus et al. 1998). In retrospect, it seems likely that the conditions used in the IGF-I/IGFBP-1 study $\left(30{ }^{\circ} \mathrm{C}\right.$ and $\left.\mathrm{pH} 3 \cdot 4\right)$, did not favour complex formation and that the small chemical shift differences that were observed arose from a variety of factors.

In this study we have investigated the interactions of bovine IGFBP-2 with both IGF-I and -II by monitoring NMR chemical shift perturbations. Good-quality spectra were obtained for both complexes, allowing the IGFBP-2 binding surfaces of both IGFs to be mapped.

\section{Materials and methods}

\section{Protein production}

Recombinant human IGF was expressed and purified from Escherichia coli JM101 cells ((supE thi-1 $\Delta$ (lacproAB) [F' traD36 proAB laclqZ $\Delta \mathrm{M} 15]$ ) as described previously (King et al. 1992, Francis et al. 1993). Briefly, $E$. coli containing the IGF expression vectors 
pGH(1-11)-VN-IGF-I (Francis et al. 1993), pGH(1-11)VNPAPH-IGF-II (Lien et al. 2001) or pGH(1-11)VNFAHY-IGF-II (Francis et al. 1993) were maintained in minimal medium with $60 \mathrm{mM}\left({ }^{15} \mathrm{NH}_{4}\right)_{2} \mathrm{SO}_{4}$ as the sole source of nitrogen in 21 bioreactors (Applikon Bioreactor, Schiedam, Holland) as described by King et al. (1992). IGF-I and -II were also expressed in minimal medium containing $50 \% \mathrm{H}_{2} \mathrm{O}$ (Sigma) in order to produce uniformly ${ }^{15} \mathrm{~N}$-labelled and random fractionally deuterated IGF-I and -II. $\left[{ }^{13} \mathrm{C} /{ }^{15} \mathrm{~N} /{ }^{2} \mathrm{H}\right] \mathrm{IGF}-\mathrm{I}$ was synthesized by growth in media containing $10 \mathrm{~g} / \mathrm{l}$ of uniformly labelled $\left[{ }^{13} \mathrm{C}\right]$ glucose (Cambridge Isotopes, MA, USA) as well as ${ }^{2} \mathrm{H}_{2} \mathrm{O}$ and $\left({ }^{15} \mathrm{NH}_{4}\right)_{2} \mathrm{SO}_{4}$. Protein was recovered from inclusion bodies by resuspending in $8 \mathrm{M}$ guanidine $\mathrm{HCl}$ followed by desalting on the fast protein liquid chromatograph using a $50 \times 200 \mathrm{~mm}$ column packed with Sephadex G-25 M (Pharmacia). IGF-I was released from the fusion partner by hydroxylamine cleavage while IGF-II was cleaved from its fusion partner by either $\alpha$-lytic protease (Lien et al. 2001) or H64A subtilisin (Francis et al. 1993). Separation of the IGF-I leader required further purification by cation exchange chromatography (Mono S column, Amersham). Final purification of correctly cleaved and folded IGFs was achieved on a C4 reverse phase HPLC column using an acetonitrile/trifluoroacetic acid gradient. N-terminal amino acid sequence analysis of the first five residues confirmed the identity and purity of each of the recombinant proteins as follows: $\left.{ }^{15} \mathrm{~N}\right] \mathrm{IGF}-\mathrm{I}$ (87\% pure), $\left[{ }^{15} \mathrm{~N} /{ }^{2} \mathrm{H}\right]$ IGF-I $(93 \%),\left[{ }^{13} \mathrm{C} /{ }^{15} \mathrm{~N} /{ }^{2} \mathrm{H}\right]$ IGF-I $(90 \%),\left[{ }^{15} \mathrm{~N}\right]$ IGF-II $(96 \%)$ and $\left[{ }^{15} \mathrm{~N} /{ }^{2} \mathrm{H}\right]$ IGF-II $(90 \%)$. Mass spectrometry was used to determine the level of isotope incorporation. Trx ${ }^{1-279}$ IGFBP-2 and Trx ${ }^{1-}$ 132IGFBP-2, fusion proteins of full-length bovine IGFBP-2 and the IGFBP-2 N-domain respectively, with thioredoxin, were produced in E. coli BL21 cells as described previously (Carrick et al. 2001). The thioredoxin fusion protein was removed by cleavage with EkMax enterokinase (Invitrogen) to yield ${ }^{1-279}$ IGFBP. All protein concentrations were determined by reversephase HPLC using Long-[ $\left.\mathrm{Arg}^{3}\right]$-IGF-I (Laajoki et al. 1997) as a standard.

\section{Biosensor analysis}

Kinetic analyses were performed with IGF-I and -II immobilised to the CM5 gold chip as described by Carrick et al. (2001). Bovine IGFBP-2 analyte in McIlvaine's citric acid phosphate running buffer $(\mathrm{pH}$ $3 \cdot 4,4 \cdot 4,5 \cdot 4,6 \cdot 4$ or $7 \cdot 4$ ) was passed over the IGF biosensor surfaces equilibrated at the same $\mathrm{pH}$ at a flow rate of $40 \mu \mathrm{l} / \mathrm{min}$. The association and dissociation phases of the interaction were recorded as described previously (Carrick et al. 2001). Samples were injected in duplicate in random order in at least two separate experiments. IGF biosensor surfaces were regenerated with $10 \mathrm{mM} \mathrm{HCl}$. Analysis of kinetic data was performed with BIAevaluation $3 \cdot 2$ software (Biacore International Ltd, Box Hill, Victoria, Australia). For each binding curve the response obtained using control surfaces (no protein coupled) was subtracted. IGFBP-2 binding fitted a 1:1 Langmuir binding model using global fitting; this model describes a simple reversible interaction of two molecules in a 1:1 complex. Goodness of fit measured as a $\chi^{2}$ value was $\leq 0.5$ for all experiments. All binding experiments were repeated at least in duplicate and biosensor chips coupled at different times yielded surfaces with very similar binding affinities.

\section{Gel filtration}

Bovine IGFBP-2 and Trx ${ }^{1-279}$ IGFBP were analysed by gel filtration on a Superdex 200 column (Pharmacia) and SMART system (Amersham). Protein samples were loaded on to the column at a concentration of $7.5 \mathrm{mg} / \mathrm{ml}$ in phosphate buffer, $150 \mathrm{mM} \mathrm{NaCl}, \mathrm{pH} 6 \cdot 4$, at a flow rate of $40 \mu \mathrm{l} / \mathrm{min}$ and compared with the high molecular mass standards: thyroglobulin $(669 \mathrm{kDa})$, ferritin $(440 \mathrm{kDa})$, human $\operatorname{IgG}(160 \mathrm{kDa})$, transferrin $(81 \mathrm{kDa})$, ovalbumin $(43 \mathrm{kDa})$, myoglobin $(17 \cdot 6 \mathrm{kDa})$ and vitamin B12 (1.4 kDa) (Sigma and Pharmacia).

\section{NMR spectroscopy}

$\left.{ }^{15} \mathrm{~N} /{ }^{2} \mathrm{H}\right]$ IGF-I, $\quad\left[{ }^{13} \mathrm{C} /{ }^{15} \mathrm{~N} /{ }^{2} \mathrm{H}\right]$ IGF-I and $\quad\left[{ }^{15} \mathrm{~N} /\right.$ ${ }^{2} \mathrm{H}$ ]IGF-II were analysed by NMR either alone or in complex with $\operatorname{Trx}^{1-279}$ IGFBP at $0.5 \mathrm{mM}$ and $\mathrm{pH} 5.0$ in $95 \% 10 \mathrm{mM}$ sodium acetate containing $5 \%{ }^{2} \mathrm{H}_{2} \mathrm{O}(\mathrm{v} / \mathrm{v})$. Complexes were prepared by dissolving lyophilized IGF-I or IGF-II in $550 \mu \mathrm{l}$ sodium acetate- ${ }^{2} \mathrm{H}_{4}$ buffer to a final concentration of $0.5 \mathrm{mM}$ prior to addition of lyophilized $\operatorname{Trx}^{1-279}$ IGFBP or $\operatorname{Trx}^{1-132}$ IGFBP-2 $(0.5 \mathrm{mM})$. Sample $\mathrm{pH}$ was adjusted to $4 \cdot 9-5 \cdot 0$ prior to NMR.

NMR spectra were recorded on Bruker AMX-500 or DRX-600 spectrometers with a probe temperature of $34^{\circ} \mathrm{C}$. Spectra were also recorded at 27,30 and $45^{\circ} \mathrm{C}$ as indicated. Typically, 512 scans were acquired per increment, with 70-90 $t_{1}$ increments and recycle times of 1.8 and $1.4 \mathrm{~s}$ for one- and two-dimensional spectra respectively. Final matrix sizes were 2048 and 1024 points in the ${ }^{1} \mathrm{H}$ and ${ }^{15} \mathrm{~N}$ dimensions respectively. Presaturation or pulsed-field gradients were used to suppress the water resonance (Sklenar et al. 1993). ${ }^{1} \mathrm{H}$ sweep widths were 5813.95 and $7122.5 \mathrm{~Hz}$ at 500 and $600 \mathrm{MHz}$ respectively. Spectra were processed and analysed on Silicon Graphics workstations using XWINNMR (version $1 \cdot 3$, Bruker) and assigned using XEASY (Bartels et al. 1995). NMR spectra included: two-dimensional ${ }^{1} \mathrm{H}-{ }^{15} \mathrm{~N}$ HSQG, two-dimensional ${ }^{1} \mathrm{H}-$ ${ }^{15} \mathrm{~N}$ TROSY, two-dimensional ${ }^{15} \mathrm{~N}$-filtered ${ }^{1} \mathrm{H}-{ }^{1} \mathrm{H}$ 
Table 1 Kinetics of the interactions of IGFBP-2 and Trx ${ }^{1-279}$ GGFBP-2 with IGF-I and -II using the 1:1 Langmuir binding model

\begin{tabular}{|c|c|c|c|c|c|c|c|}
\hline & $\begin{array}{l}\boldsymbol{k}_{\mathrm{a}} \\
\left(\times 10^{4}\right)\end{array}$ & $\begin{array}{l}\text { Relative } \\
\boldsymbol{k}_{\mathrm{a}}\end{array}$ & $\begin{array}{l}\boldsymbol{k}_{\mathrm{d}} \\
\left(\times 10^{-4}\right)\end{array}$ & $\begin{array}{l}\text { Relative } \\
\boldsymbol{k}_{\mathrm{d}}\end{array}$ & $\begin{array}{l}K_{\mathrm{d}} \\
\left(\times 10^{-9}\right)\end{array}$ & $\begin{array}{l}\text { Relative } \\
K_{\mathrm{d}}\end{array}$ & $\chi^{2}$ \\
\hline \multicolumn{8}{|l|}{ IGF-I } \\
\hline bIGFBP-2 & 4.47 & 1.00 & $1 \cdot 29$ & 1.00 & 2.89 & 1.00 & 0.46 \\
\hline \multicolumn{8}{|l|}{ IGF-II } \\
\hline bIGFBP-2 & $2 \cdot 78$ & 1.00 & $1 \cdot 19$ & 1.00 & $4 \cdot 27$ & 1.00 & 0.38 \\
\hline Trx 1-279|GFBP-2 & $2 \cdot 48$ & 0.89 & 0.64 & 0.54 & $2 \cdot 60$ & 0.61 & 0.33 \\
\hline
\end{tabular}

The 1:1 Langmuir binding model was used to fit kinetic data for the interaction between IGFBP-2 and Trx ${ }^{1-279}$ IGFBP-2 across both IGF-I and -II biosensor surfaces at $\mathrm{pH} 7 \cdot 4$. Association rates $\left(k_{\mathrm{a}}\right)$, dissociation rates $\left(k_{\mathrm{d}}\right)$, and dissociation constants $\left(K_{\mathrm{d}}=k_{\mathrm{d}} / k_{\mathrm{a}}\right)$ are given. Dissociation constants relative to IGFBP-2 for IGF-I and -II biosensor surfaces are also presented $\left(K_{\mathrm{d}}\right.$ bIGFBP-2/ Trx ${ }^{1-279}$ IGFBP-2). The association and dissociation rates are also given relative to IGFBP-2 for IGF-I -II biosensor surfaces.

NOESY with a $150 \mathrm{~ms}$ NOESY mixing period and three-dimensional HNCA. Spectra were referenced to an internal peak at $0 \cdot 15$ p.p.m. in the ${ }^{1} \mathrm{H}$ dimension and indirectly using the experimentally determined frequency ratios for ${ }^{15} \mathrm{~N}(0 \cdot 101329118+(T-300 \mathrm{~K}) \times$ $\left.2 \cdot 74 \times 10^{-10}\right)$ and ${ }^{13} \mathrm{C}(0.251449530+(T-300 \mathrm{~K}) \times$ $\left.1 \cdot 04 \times 10^{-9}\right)$, where $T$ is the sample temperature (Wishart et al. 1995).

A three-dimensional NOESY-TROSY spectrum (Zhu et al. 1998, 1999) was also recorded on the complex between $\left[{ }^{15} \mathrm{~N} /{ }^{2} \mathrm{H}\right] \mathrm{IGF}-\mathrm{II}$ and $\mathrm{Trx}{ }^{1-279} \mathrm{IGFBP}$ at 750 $\mathrm{MHz}$ on a Varian Inova 750.

\section{Results}

\section{Comparison of IGFBP-2 and Trx ${ }^{1-279 / G F B P-2}$ for NMR studies}

Trx ${ }^{1-279}$ IGFBP-2 and IGFBP-2 interact similarly with IGF-I and -II immobilised on biosensor surfaces at $\mathrm{pH} 7 \cdot 4$, and the binding kinetics derived using a 1:1 Langmuir binding model are essentially the same (Table 1). IGFBP-2 exhibits similar biosensor curves at $\mathrm{pH} 7 \cdot 4,6 \cdot 4$ and $5 \cdot 4$, but the dissociation from IGF is slightly faster at $\mathrm{pH} 4 \cdot 4$ and significantly faster at $\mathrm{pH} 3 \cdot 4$ (Fig. 2). Consequently, our NMR studies of the changes in IGF chemical shifts upon binding of IGFBP-2 were conducted at approximately $\mathrm{pH} \mathrm{5,} \mathrm{where} \mathrm{strong} \mathrm{binding}$ was observed but self-association of IGF-I and -II (see below) was not so extensive as to prevent the observation of spectra for the free ligands. Our previous BIAcore analyses show that IGFBP-2 and IGF-II form a $1: 1$ complex (Carrick et al. 2001), as was also previously established by Bourner et al. (1992) using Scatchard analysis.

The thioredoxin fusion partner contributed to the solubility of proteins during expression in E. coli, and restricted aggregation of the purified protein. The quaternary states of IGFBP-2 and Trx ${ }^{1-279}$ IGFBP-2 were analysed at millimolar concentrations by gel filtration. While IGFBP-2 formed large oligomeric aggregates at high protein concentrations and neutral $\mathrm{pH}, \quad$ Trx ${ }^{1-279}$ IGFBP-2 remained monomeric under identical gel filtration conditions (Fig. 3).

\section{Spectra of free IGF-I and -II}

IGF-I and -II have been difficult to study structurally because they contain regions of high mobility, undergo conformational averaging and aggregate in solution at millimolar concentrations. Because of these problems, IGF-I and -II yield poorer quality NMR spectra at $\mathrm{pH}$ values above 3. Sato and co-workers reported an improvement in IGF-I spectral quality upon addition of $10 \%$ (Sato et al. 1992) or $20 \%$ acetic acid (Sato et al. 1993), although the same was not true for IGF-II

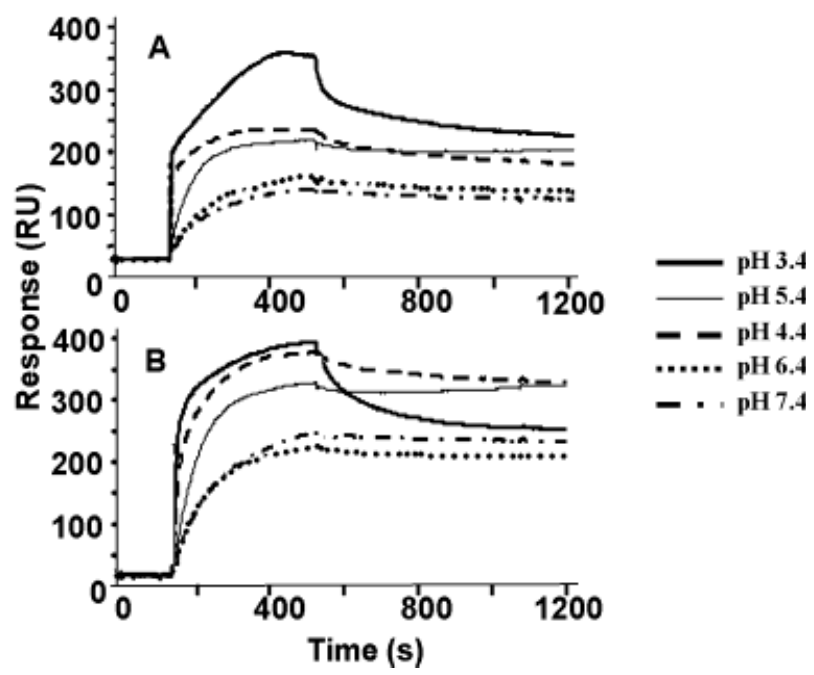

Figure 2 BIAcore analysis of the effect of $\mathrm{pH}$ on IGF-IGFBP interaction. Sensorgrams are presented for the interaction of IGFBP-2 (100 nM) with (A) IGF-I and (B) IGF-II biosensor surfaces in citric acid running buffer at $\mathrm{pH} 3.4,4.4,5.4,6.4$ and 7.4. Biosensorgrams were recorded at a flow rate of $40 \mu \mathrm{l} / \mathrm{min}$. 


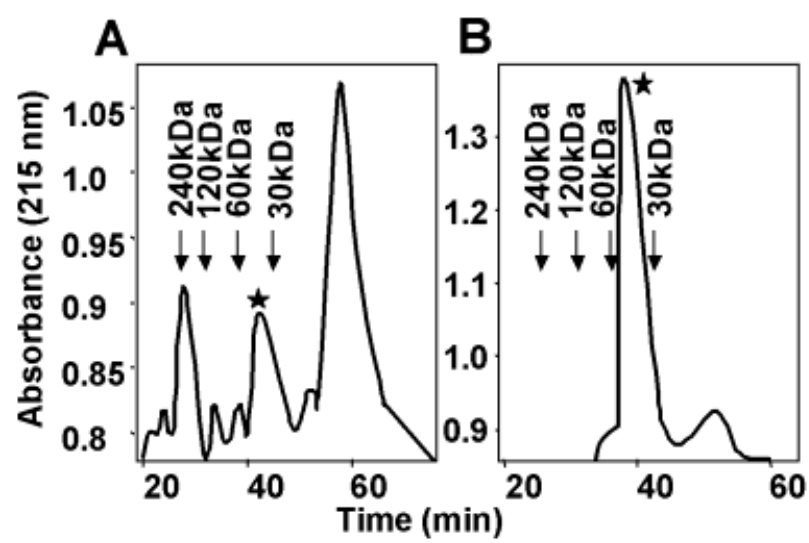

Figure 3 Gel filtration of IGFBP-2 and Trx ${ }^{1-279}$ IGFBP-2. Proteins were loaded onto a Superdex 200 column at a concentration of $7.5 \mathrm{mg} / \mathrm{ml}$ in phosphate buffer $(\mathrm{pH} \mathrm{6.5)}$ at a flow rate of $40 \mu \mathrm{l} / \mathrm{min}$. The elution profiles of (A) $200 \mu \mathrm{g}$ IGFBP-2 and (B) $300 \mu \mathrm{g}$ Trx ${ }^{1-279}$ GFFBP-2 were compared with the molecular mass standards thyroglobulin $(669 \mathrm{kDa})$, ferritin (440 kDa), human IgG (160 kDa), transferrin (81 kDa), ovalbumin (43 kDa), myoglobin (17.6 kDa) and vitamin B12 $(1.4 \mathrm{kDa})$. Absorbance was detected at $215 \mathrm{~nm}$ and masses are shown above (in kDa). IGFBP-2 at $30 \mathrm{kDa}$ and Trx ${ }^{1-279}$ IGFBP-2 at $50 \mathrm{kDa}$ are highlighted with asterisks.

(Torres et al. 1995). Attempts to crystallize IGF have only recently been successful and then only as complexes with other molecules (Vajdos et al. 2001, Zesławski et al. 2001).

Before attempting to define the IGFBP binding sites on IGF-I and -II, we recorded a series of twodimensional ${ }^{1} \mathrm{H}^{-15} \mathrm{~N}$ NMR spectra on the free ligands. Both ${ }^{15} \mathrm{~N}$ - and ${ }^{2} \mathrm{H} /{ }^{15} \mathrm{~N}$-labelled IGF-I and -II were examined. Partial deuteration of the IGF ligands significantly improved the quality of HSQG and TROSY spectra compared with the fully protonated samples. Broad peaks evident in the spectrum of $\left[{ }^{15} \mathrm{~N}\right]$ IGF-I were sharpened significantly upon partial deuteration of the ligand and several additional peaks were observed (see Supplementary Material available at http://www.wehi.edu.au/resources/norton). Furthermore, the TROSY spectrum of $\left[{ }^{15} \mathrm{~N}\right]$ IGF-I was much improved over the HSQG spectrum of the equivalent sample recorded at $600 \mathrm{MHz}, \mathrm{pH} 4.8$ and $30^{\circ} \mathrm{C}$, although Asn and Gln side-chain resonances were weaker in the TROSY spectra, as expected (Pervushin et al. 1997, Fernández \& Wider 2003).

\section{Resonance assignments for IGF-I}

There are significant differences among chemical shift values reported in the literature for IGF-I (Cooke et al. 1991, Sato et al. 1992), Long-[Arg $\left.{ }^{3}\right]$-IGF-I (Laajoki et al. 1997) and Long-[Leu $\left.{ }^{60}\right]$-IGF-I (BioMagResBank (www.bmrmbmrb.wisc.edu), accession number BMRB6311). Variations between ${ }^{1} \mathrm{H}$ chemical shifts reported by Cooke et al. (1991) and Sato et al. (1992) are small and probably reflect the different temperatures at which spectra were acquired $\left(50{ }^{\circ} \mathrm{C}(\mathrm{pH} 2 \cdot 9)\right.$ and $40{ }^{\circ} \mathrm{C}(\mathrm{pH} 3)$ respectively). The ${ }^{1} \mathrm{H}$ chemical shifts published by Laajoki et al. (1997) for $\left[{ }^{15} \mathrm{~N}\right]$ Long-[Arg $\left.^{3}\right]-$ IGF-I, by contrast, vary significantly from the earlier values (Cooke et al. 1991, Sato et al. 1992), more so than would be expected for variation in temperature $\left(30^{\circ} \mathrm{C}\right)$ and $\mathrm{pH}$ $(4 \cdot 1)$. This was despite the fact that the 13 -residue N-terminal extension and mutation of $\mathrm{Glu}^{3}$ to $\mathrm{Arg}$ were reported to have little effect on the secondary structure of IGF-I (Laajoki et al. 1997). The chemical shifts for Long-[ $\left.\mathrm{Arg}^{3}\right]$-IGF-I also differ significantly from those for Long-[Leu $\left.{ }^{60}\right]$-IGF-I, even though these two proteins differ at only two positions. Jansson et al. (1998) assigned $\mathrm{HN},{ }^{15} \mathrm{~N},{ }^{13} \mathrm{C}^{\alpha}$ and ${ }^{13} \mathrm{C}^{\beta}$ chemical shifts in IGF-I at $\mathrm{pH}$ 3.4 and 50 or $30^{\circ} \mathrm{C}$, but the chemical shifts were not documented or deposited in a database. More recently, Schaffer et al. (2003) investigated the structure of IGF-I with a bound peptide identified by phage display (IGF-F1-1). This complex gave considerably better NMR spectra than free IGF-I, such that all backbone amide resonances could be observed in an ${ }^{15} \mathrm{~N}$ HSQG spectrum. However, several resonances were shifted as a result of the peptide binding.

Assignments for free IGF-I in the current study were made initially by comparison with the various literature values (summarized in Supplementary Material), but the differences among them created several ambiguities. These were partially resolved by analysis of a threedimensional NOESY-HSQG spectrum on $\left[{ }^{15} \mathrm{~N}\right] \mathrm{IGF}-\mathrm{I}$ (not shown). Assignments were made for all residues except the N-terminal Gly and the prolines at positions 2, 28, 39, 63 and 66, which do not give rise to resonances in two-dimensional ${ }^{1} \mathrm{H}^{-15} \mathrm{~N}$ spectra (Supplementary Material); resonances from $\mathrm{Gly}^{7}, \mathrm{Ala}^{8}$ and $\mathrm{Leu}^{10}$ were not visible in spectra even at different temperatures and $\mathrm{pH}$ (30 and $45^{\circ} \mathrm{C}$, pH $2 \cdot 9$ and $4 \cdot 1$ ).

\section{IGF-I interaction with full-length IGFBP-2}

NMR spectra of IGF-I and -II bound to $\operatorname{Trx}^{1-279}$ IGFBP-2 were acquired at $\mathrm{pH} 5$ to ensure near wild-type binding kinetics at physiological temperature (see above). At equimolar concentrations of IGF and IGFBP-2, each around $0.5 \mathrm{mM},>99.9 \%$ of the ligand should be bound in solution, assuming a $K_{\mathrm{d}}$ of $10 \mathrm{nM}$. Limited information could be derived from HSQC spectra of the complexes as many of the resonances were no longer evident. By contrast, TROSY spectra at 600 $\mathrm{MHz}$ of deuterated $\left[{ }^{15} \mathrm{~N}\right]$ IGF-I and $\left[{ }^{15} \mathrm{~N}\right] \mathrm{IGF}-\mathrm{II}$ in complex with Trx ${ }^{1-279}$ IGFBP-2 showed the expected number of resonances for each ligand.

The observation of separate sets of resonances for the free and bound forms of IGF-I indicates that essentially all of the IGF-I was bound under the conditions of the 


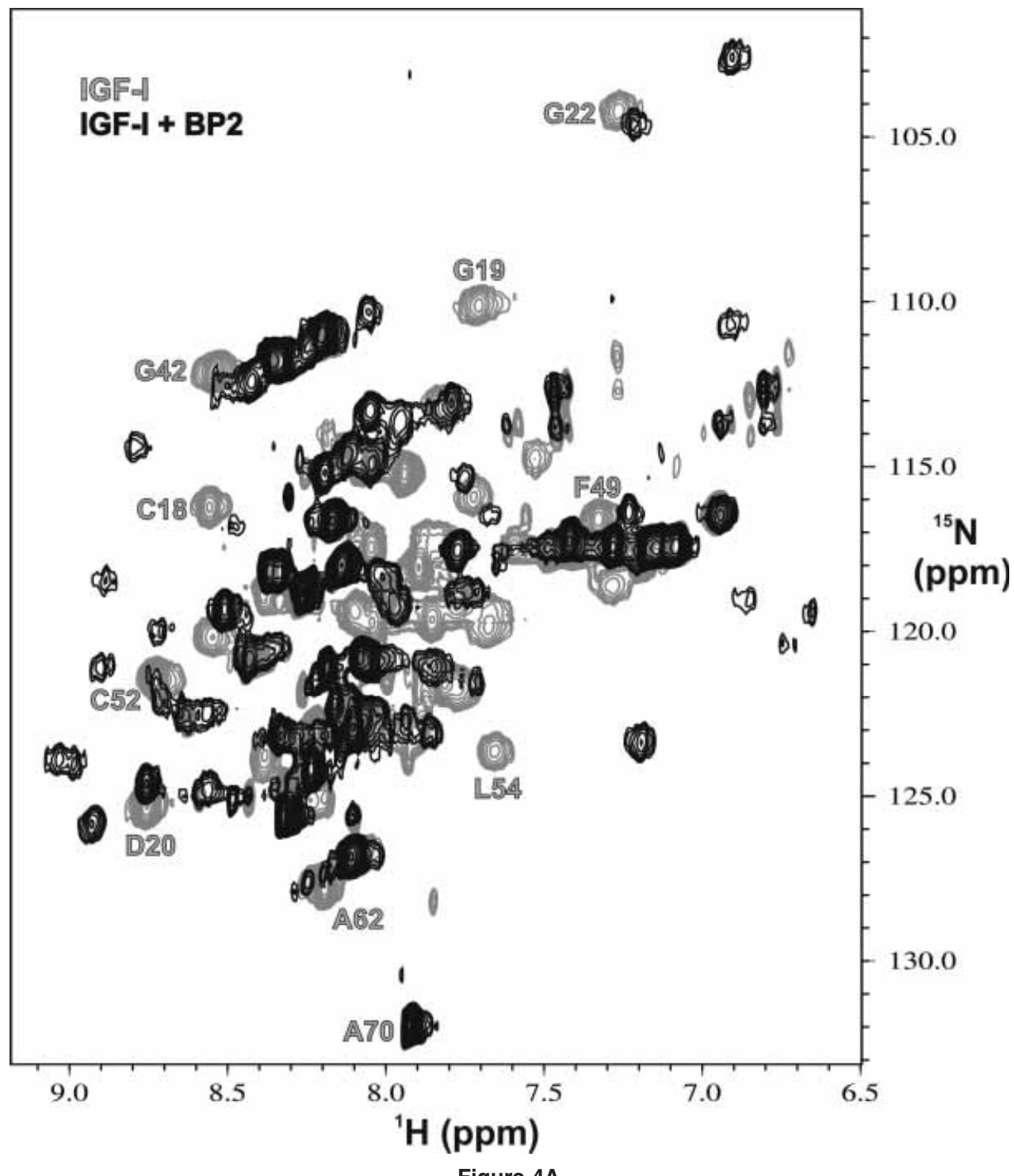

Figure 4A

NMR experiment and that the free and bound forms were in slow exchange on the NMR time scale (Lian \& Roberts 1993), both of which are consistent with the low nanomolar $K_{\mathrm{d}}$ values obtained from biosensor measurements (Table 1). The task of assigning resonances of IGF-I in the complex would have been straightforward had the free and bound forms been in fast exchange, where a single resonance would be observed for each backbone amide at a position determined by the resonance positions in the free and bound states and their relative populations. To explore whether this condition could be achieved at lower $\mathrm{pH}$, where binding affinity is reduced (Fig. 2), NMR spectra were acquired at $37^{\circ} \mathrm{C}$ and $\mathrm{pH}$ values of $5 \cdot 1,3 \cdot 8,3 \cdot 5$ and $2 \cdot 8$. At $\mathrm{pH}$ 3.8 and 3.5 the complex remained intact, with shifts essentially the same as at $\mathrm{pH} 5$, while at $\mathrm{pH} 2 \cdot 8$ the spectrum resembled that of the free ligand. Clearly, the binding affinity declined significantly below $\mathrm{pH} 3 \cdot 4$, but exchange between free and bound IGF-I remained in the slow limit (Lian \& Roberts 1993) down to this $\mathrm{pH}$. Apparently IGF-I binding to $\operatorname{Trx}^{1-279}$ IGFBP-2 in the NMR experiments was stronger than implied by the biosensor data, suggesting that future NMR studies could be carried out at a lower $\mathrm{pH}$, around 4, where the spectra of free IGF-I and -II (see below) were less affected by aggregation.

At $37^{\circ} \mathrm{C}$ and $\mathrm{pH} 5 \cdot 1$ a large number of peaks in the TROSY spectrum of IGF-I shifted upon binding to Trx ${ }^{1-279}$ IGFBP-2, as shown in Fig. 4A. Assignment of the shifted peaks in the complex was not possible 


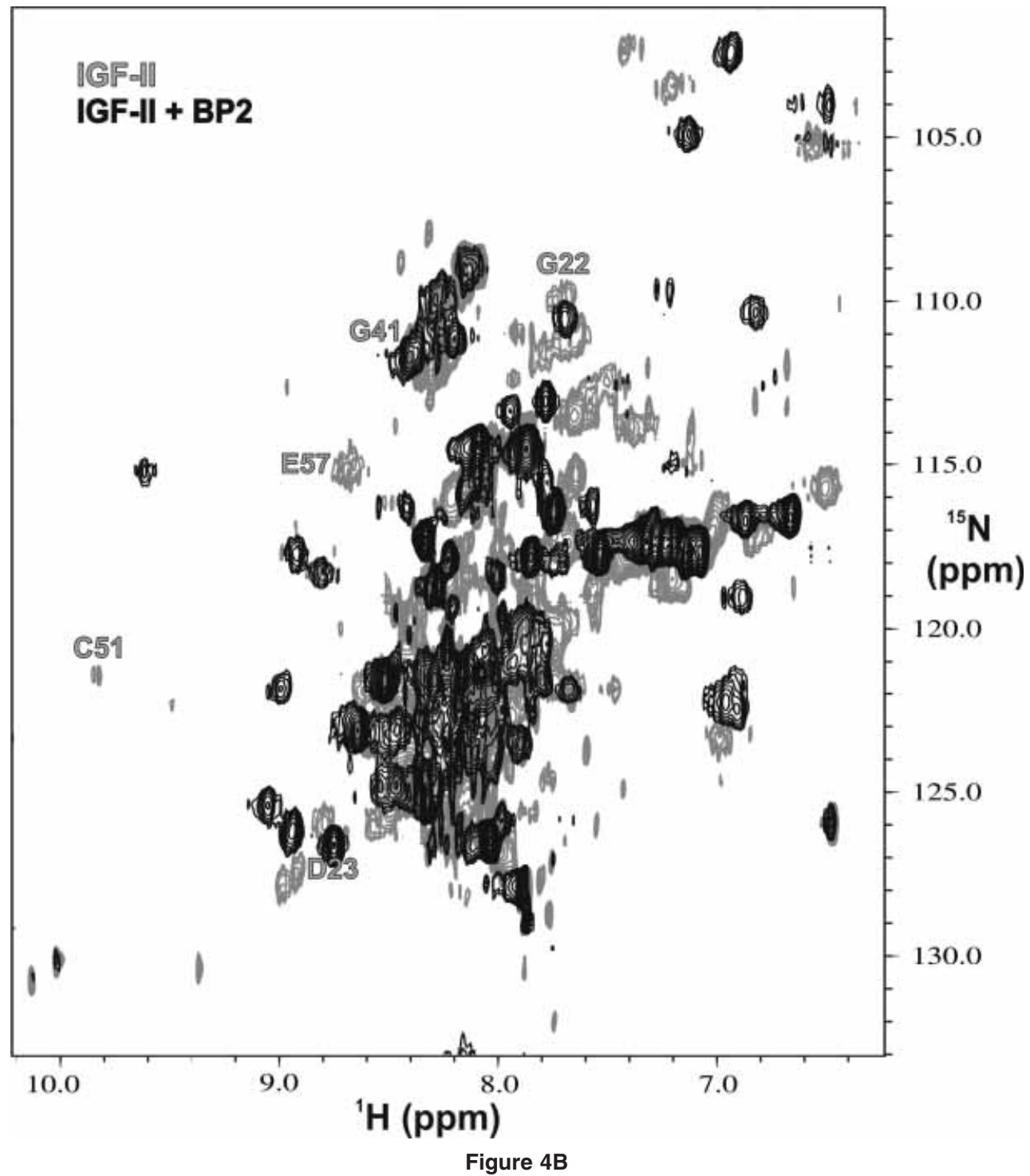

Figure 4 TROSY spectra of: (A) free IGF-I (grey) and IGF-I in complex with Trx ${ }^{1-279 \mid G F B P-2 ~(b l a c k), ~}$ and (B) free IGF-II (grey) and IGF-II in complex with Trx ${ }^{1-279}$ IGFBP-2 (black) Spectra were acquired at $600 \mathrm{MHz}$ and $34{ }^{\circ} \mathrm{C}$, at $\mathrm{pH} 5.1$ for free ligands and $\mathrm{pH} 4.8$ for the complexes. Spectra were referenced to an intrinsic peak at 0.15 p.p.m. and overlaid for comparison using XEASY (Bartels et al. 1995). Note that the TROSY spectra shown in this figure have backbone amide chemical shifts that differ from those in conventional HSQC spectra by approximately $+0.7-0.8$ p.p.m. in the ${ }^{15} \mathrm{~N}$ dimension and -0.08 p.p.m. in the ${ }^{1} \mathrm{H}$ dimension, as expected (Pervushin et al. 1997). A colour version of this figure is available in the Supplementary Material.

because a three-dimensional NOESY-TROSY spectrum could not be obtained in a reasonable time for this size complex at $0.5 \mathrm{mM}$. Our interpretation of the spectral perturbations is therefore based on classification of IGF-I peaks as either 'not shifted' relative to free IGF-I, 'shifted' or 'disappeared'. Shifted peaks are defined as those that had moved in one or both of the ${ }^{1} \mathrm{H}$ and ${ }^{15} \mathrm{~N}$ dimensions but were still close enough to the corresponding peak in free IGF-I to be assignable, for example Cyss ${ }^{18}$ and $\mathrm{Asp}^{20}$ in Fig. 4A, while peaks classified as disappeared had moved far enough in the complex that they could not be assigned by comparison with the spectrum of free IGF-I, for example Gly ${ }^{19}$ and $\mathrm{Leu}^{54}$ in Fig. 4A. Following these definitions, Glu ${ }^{9}$, $\mathrm{Leu}^{14}, \mathrm{Gln}^{15}$, Phe ${ }^{16}$, Gly ${ }^{19}, \mathrm{Phe}^{25}$, Leu ${ }^{54}$ and $\mathrm{Leu}^{57}$ experienced large shifts (disappeared), while $\mathrm{Thr}^{4}, \mathrm{Leu}^{5}$, 
$\mathrm{Val}^{11}, \mathrm{Val}^{17}, \mathrm{Cys}^{18}, \mathrm{Asp}^{20}, \mathrm{Gly}^{22}, \mathrm{Tyr}^{24}, \mathrm{Lys}^{27}, \mathrm{Gly}^{42}$, $\mathrm{Glu}^{46}, \mathrm{Cys}^{48}, \mathrm{Phe}^{49}, \mathrm{Arg}^{50}, \mathrm{Asp}^{53}, \mathrm{Tyr}^{60}, \mathrm{Ala}^{62}$ and Lys $^{65}$ experienced smaller shifts. These residues are highlighted in the sequence of IGF-I in Fig. 5A.

\section{IGF-I interaction with the N-terminal domain of IGFBP-2}

Carrick et al. (2001) demonstrated using BIAcore analysis that high-affinity binding to IGF-I or -II could only be achieved when both the amino- and carboxyl-terminal domains of IGFBP-2 are present and covalently linked. In an attempt to further define the differences between the amino- and carboxyl-terminal binding domains of IGFBP-2, we investigated the interaction of IGF-I with Trx ${ }^{1-132}$ IGFBP-2, which contains just the N-domain. Under the solution conditions used for the full-length protein $(0.5 \mathrm{mM}$ IGF-I and binding protein), complex formation with the $\mathrm{N}$-domain was incomplete, with the peaks shifted in the complex corresponding to about $20 \%$ of the total IGF-I (spectra not shown). Clearly the $\mathrm{N}$-domain binds IGF-I less strongly than full-length IGFBP-2 under these conditions, even though the $K_{\mathrm{d}}$ obtained from biosensor measurements (Carrick et al. 2001) would predict nearly $100 \%$ complex formation at $0.5 \mathrm{mM}$. Binding was still tight enough for the free and bound forms to be in slow exchange. Spectra acquired at a lower temperature $\left(27^{\circ} \mathrm{C}\right)$ did not significantly influence the proportion of free and bound ligand. Because there was substantial residual intensity for all peaks of the free ligand, it was difficult to determine which peaks that shifted in the complex with full-length protein were not shifted in the presence of the $\mathrm{N}$-domain. However, it was clear that several peaks in the spectrum of the full-length complex were not present in the spectrum of the $\mathrm{N}$-domain complex, for example the cross-peaks at $8 \cdot 9 / 119,8 \cdot 8 / 114$ and $8 \cdot 7 / 120$ p.p.m. in Fig. 4, as well as several peaks from side chains in the region $6 \cdot 6-7 \cdot 2$ p.p.m. One peak that clearly does not shift in the presence of the $\mathrm{N}$-domain is Gly ${ }^{19}$, indicating that its significant shift in the presence of full-length IGFBP-2 (Fig. 4) arises from interactions with the C-domain.

\section{IGF-II assignments}

Spectra of IGF-II were less dispersed than those of IGF-I, containing a number of broad signals attributable to aggregation and/or conformational averaging. As reported by Torres et al. (1995), the presence of broad peaks presents problems with spectral analysis and resonance assignments. TROSY spectra of IGF-II were acquired at $34^{\circ} \mathrm{C}$ and $\mathrm{pH} 4.8$ and resonances were assigned based on those of Torres et al. (1995) at $27^{\circ} \mathrm{C}$ and $\mathrm{pH} 3 \cdot 1$, although the higher $\mathrm{pH}$ used in our study caused additional line broadening and therefore greater peak overlap. Our chemical shifts for IGF-II were within 0.06 p.p.m. of reported values (Torres et al. 1995) for the amide proton dimension (except for $\mathrm{Leu}^{8}$, at 0.09 p.p.m.) but differed consistently by approximately $-1 \cdot 3$ p.p.m. in the ${ }^{15} \mathrm{~N}$ dimension, presumably reflecting a difference in referencing. Weak or poorly resolved peaks were observed for several residues, including $\mathrm{Gly}^{10}$, $\mathrm{Gly}^{11}, \mathrm{Leu}^{13}, \mathrm{Leu}^{17}, \mathrm{Val}^{20}, \mathrm{Arg}^{30}, \mathrm{Cys}^{51}$ and $\mathrm{Leu}^{56}$. In addition to the expected backbone amide resonances, several other unidentified peaks were present in the spectra that correspond to side chains and residual traces of contaminating leader sequence.

\section{IGF-II interaction with full-length IGFBP-2}

As observed for IGF-I, the chemical shift perturbations upon complex formation with $\operatorname{Trx}^{1-279}$ IGFBP were large, and the free and bound forms were in slow exchange (Fig. 4B). Therefore assignments for free IGF-II could not be transferred readily to the spectra of complexed IGF-II. It is noteworthy that the quality of the IGF-II spectrum in complex with $\mathrm{Trx}^{1-279}$ IGFBP-2 is actually better than that of free IGF-II, even though the complex has a mass of $50 \mathrm{kDa}$ and the mass of monomeric IGF-II is $7 \cdot 5 \mathrm{kDa}$. The greater dispersion and improved linewidths in the spectrum of the complex indicate that at least some of the flexible and less structured regions of free IGF-II (Torres et al. 1995) appear to be stabilized in the complex, thus enhancing chemical shift dispersion. In addition, non-specific aggregation and/or conformational averaging, which are responsible for broad linewidths in spectra of free IGF-II, largely disappeared after formation of the complex. The quality of the TROSY spectrum of the Trx ${ }^{1-279}$ IGFBP-2-IGF-II complex implies that it does not self-associate in solution. A slight improvement in the spectrum of IGF-I was also evident upon complex formation (Fig. 4A) but the effect was less noticeable because free IGF-I is less prone to aggregation. Using the same approach as for IGF-I, we have classified peaks in IGF-II affected by complex formation as 'shifted' or 'disappeared', with the caveat that identification of the peaks in free IGF-II is more difficult because of the broad lines and substantial overlap. Following these definitions, Gly ${ }^{11}$, $\mathrm{Phe}^{26}$, $\mathrm{Phe}^{28}$, Glu ${ }^{45}$, Ser ${ }^{50}$, Leu ${ }^{55}$, $\mathrm{Glu}^{57}$ and $\mathrm{Thr}^{58}$ experienced large shifts (disappeared), while $\mathrm{Thr}^{7}$, Gly ${ }^{10}$, $\mathrm{Leu}^{17}, \mathrm{Gln}^{18}$, $\mathrm{Phe}^{19}$, $\mathrm{Cys}^{21}$, Gly ${ }^{22}$, $\mathrm{Asp}^{23}, \mathrm{Gly}^{25}, \mathrm{Val}^{35}, \mathrm{Gly}^{41}, \mathrm{Cys}^{47}, \mathrm{Phe}^{48}$ and $\mathrm{Cys}^{51}$ experienced smaller shifts. $\mathrm{Arg}^{49}$ and $\mathrm{Cys}^{60}$ also appear to have shifted but they are partially overlapped with side chain resonances. These residues are highlighted in the sequence of IGF-II in Fig. 5A.

The spectral resolution of IGF-II did not show a significant improvement upon addition of $\operatorname{Trx}^{1-132}$ 
IGFBP-2. Indeed, the increase in effective molecular mass resulted in broadened line widths and reduced spectral resolution compared with that of free IGF-II.
As with IGF-I, it appears that the extent of complex formation in the NMR sample is less than predicted from biosensor data. With a $K_{\mathrm{d}}$ for the

(A)

$\begin{array}{cccccc}10 & 20 & 30 & 40 & 50 & 60\end{array}$

IGF-II AYRPSETLCGGELVDTLQFVCGDRGFYF SRPASR - -VSRRS - - RGIVEECCFRSDLLAL LETYCA - TPAKSE

$10 \quad 20 \quad 30$

40

60

(B)

\section{IGF-I}
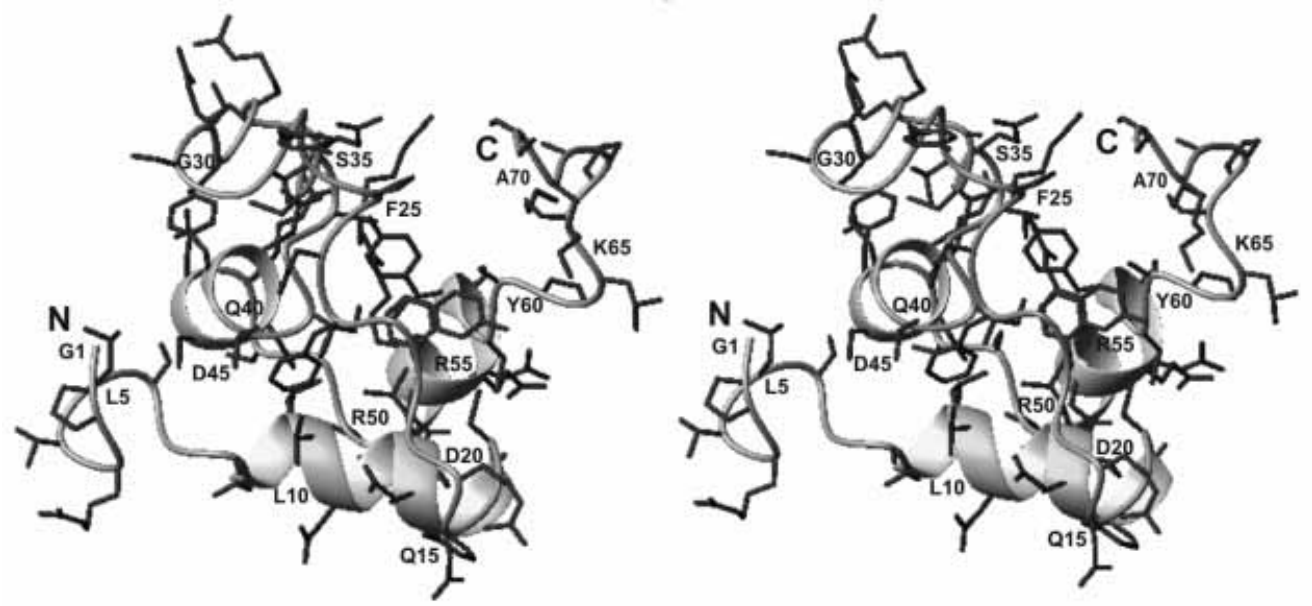

IGF-II
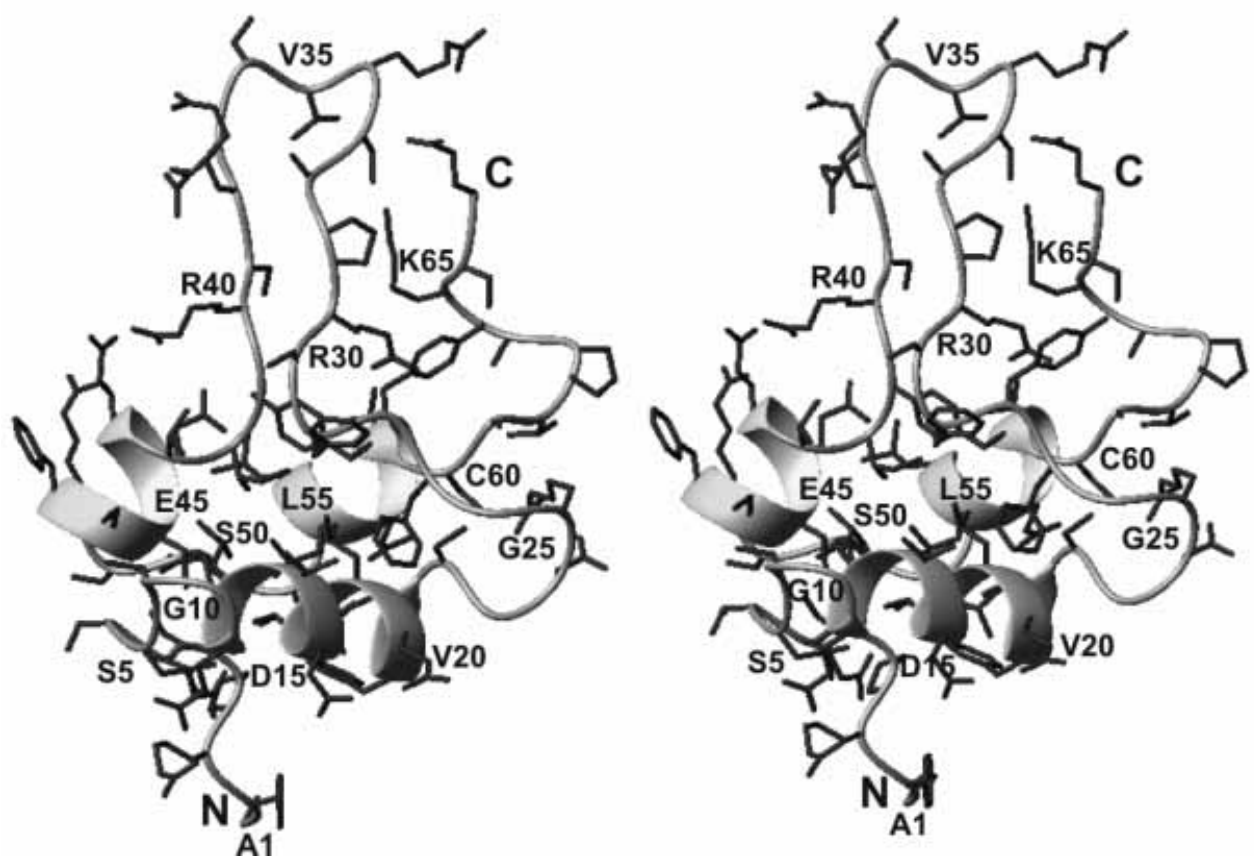
IGF-II-1-132IGFBP-2 complex of $51 \mathrm{nM}$ (Carrick et al. 2001), complex formation should have been largely complete at the $0.5 \mathrm{mM}$ concentrations of ligand and binding protein used for the NMR study, and yet the appearance of the IGF-II spectrum implies that most of it is still free.

\section{Discussion}

NMR has been used in this study in order to define the IGFBP-2 binding surfaces of IGF-I and -II. Specifically, chemical shift perturbations in ${ }^{15} \mathrm{~N}-$ and ${ }^{2} \mathrm{H} /{ }^{15} \mathrm{~N}-$ labelled IGF-I or IGF-II upon binding to unlabelled Trx ${ }^{1-279}$ IGFBP have been monitored to identify residues involved directly in the binding interaction as well as any affected by conformational changes associated with the interaction.

Analysis of perturbations of IGF resonances upon complex formation with IGFBP-2 relied on resonance assignments for the free ligands. For both IGF-I and IGF-II, resonance assignments were hampered by the lack of spectral dispersion and broad linewidths, arising from conformational averaging and the tendency of IGF-I (and even more so, IGF-II) to aggregate. Problems due to line broadening have been encountered previously in NMR studies of insulin (Kline \& Justice 1990, Hua \& Weiss 1991), IGF-I (Cooke et al. 1991, Sato et al. 1992) and IGF-II (Terasawa et al. 1994, Torres et al. 1995). In this study, deuteration of the ligand and the use of TROSY-based experiments improved spectral quality, particularly of the complexed ligand.

Chemical shift mapping is a quick and effective method for mapping protein interactive surfaces in solution as we demonstrated in our recent study of the interaction of IGF-II with the C-domain of IGFBP-6 (Headey et al. 2004b). In the current study, changes in backbone amide ${ }^{1} \mathrm{H}$ and ${ }^{15} \mathrm{~N}$ chemical shifts were used as a monitor of the IGFBP-2 binding surfaces on IGF-I and -II, with peaks classified into three groups according to the size of their shifts. A more quantitative analysis in terms of weighted average shift magnitudes was precluded by the lack of assignments for the bound state and the absence of some resonances in the free state. The lack of assignments for the bound ligands also precluded application of the method of saturation transfer (Takahashi et al. 2000, Nakanishi et al. 2002) to map the binding interface. In this technique, magnetization is transferred from the larger binding partner, in this case IGFBP-2, to the ligand being observed by NMR. Generally speaking, this approach would provide a more precise picture of the binding surface than that obtained by mapping chemical shift perturbations, which usually identify a larger interaction surface than x-ray crystallographic studies (Huang et al. 1998, Ding et al. 2000). Thus, it should be borne in mind in interpreting our results and when comparing our data with the mini-IGFBP-5 surface of IGF-I described by Zesławski et al. (2001) that the actual contact surface between the IGFs and IGFBP-2 is likely to be slightly smaller than inferred from our observed spectral perturbations.

It is unlikely that significant conformational changes occur in IGF-I or -II upon complex formation. Crystal structures have been reported recently for IGF-I in complex with mini-IGFBP-5 (Zesławski et al. 2001) and the detergent, deoxy big CHAPS (Vajdos et al. 2001), and a well-defined solution structure for IGF-I bound to a peptide derived from phage display (Schaffer et al. 2003). The overall structure of IGF-I observed in solution (Fig. 5B) is preserved in these complexes, although the loops and termini, which are less well defined in the solution structures, generally adopt more ordered structures in the complexes.

The chemical shift perturbations observed in this work for IGF-I and -II upon complex formation with Trx ${ }^{1-279}$ IGFBP were significantly greater than those reported by Jansson et al. (1998) for binding of IGF-I to IGFBP-1. It is possible that very little complex between IGF-I and IGFBP-1 was present at $\mathrm{pH} 3 \cdot 4$, as used by Jansson et al. (1998), and that the reported chemical shift differences reflect at least partly the influence of $\mathrm{pH}$ on the spectrum of free IGF-I. We performed BIAcore analyses of the binding interaction between IGF-I or IGF-II and IGFBP-2 to determine the effect of $\mathrm{pH}$ on complex formation. The binding curve at $\mathrm{pH} 3 \cdot 4$ was atypical of the high-affinity binding interaction with IGFBP-2, showing more rapid dissociation from IGF-I biosensor surfaces than at $\mathrm{pH} 4 \cdot 4$ or $5 \cdot 4$. Furthermore, TROSY spectra of the complex at various $\mathrm{pH}$ values in

Figure 5 (A) Amino acid sequences of IGF-I and -II with residues that disappeared upon IGFBP-2 binding highlighted in bold and underlined, and those that shifted in bold. Residues involved in interactions of IGF-I with mini-IGFBP-5 (Zesławski et al. 2001) and IGF-II with IGFBP-6 C-domain (Headey et al. 2004b) are shaded grey. The locations of the three $\alpha$-helices in IGF-I and -II (residues 8-18, 43-48 and 54-60; and 11-21, 42-49 and 53-59 respectively) are shown as bars above the sequences. (B) Structures of

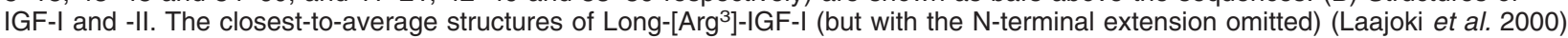
and IGF-II (Torres et al. 1995) are shown in stereo. The backbone is shown as a ribbon and the side chains as lines. The $\mathrm{C}^{\alpha}$ positions of each fifth residue are numbered. The orientations of the two structures are similar over the well-defined regions; in IGF-I this orients the tip of the poorly defined loop (encompassing the C-domain) towards the viewer whereas in IGF-II it is oriented vertically. Structures were generated in MOLMOL (Koradi et al. 1996). A colour version of this figure is available in the Supplementary Material. 
this study indicated that the complex dissociated between $\mathrm{pH} 3 \cdot 5$ and $2 \cdot 8$.

Not unexpectedly, when we compare the chemical shift differences for IGF-I and -II complexed with IGFBP-2 (highlighted residues in Fig. 5A), it is clear that the residues affected by IGFBP-2 binding are similar in both cases. This reflects the relatively similar binding affinities (Table 1). Some of the differences between the residues highlighted in Fig. 5A for IGF-I and -II reflect problems arising from spectral overlap and broad resonances. For example, $\mathrm{Gly}^{7}$ and $\mathrm{Ala}^{8}$ are not visible in our spectra of free IGF-I, while $\mathrm{Leu}^{53}$ in IGF-II is heavily overlapped with other peaks. Comparing the highlighted residues in Fig. 5A with the 12 IGF-I residues identified by Zesławski et al. (2001) as lying within $4 \AA$ of mini-IGFBP-5 in the crystal structure of the complex (Fig. 1), the first six (from the IGF-I B-domain) are in close agreement, being either perturbed upon binding to IGFBP-2 or adjacent to residues that are perturbed. There is $63 \%$ sequence similarity between mini-IGFBP-5 and the corresponding region of IGFBP-2 so a significant correlation between the two binding sites in this region is expected. The remaining six contact residues occur between $\mathrm{Cys}^{52}$ and $\mathrm{Glu}^{58}$ in IGF-I, and chemical shift perturbations with IGFBP-2 are observed for various residues from this region of IGF-I and -II.

There are also some interesting differences between our results and the mini-IGFBP-5 study. In both IGF-I and -II we see significant perturbations in the Gly $^{22}-\mathrm{Phe}^{25}$ region (Fig. 5A). Mutational analyses have previously shown that $\mathrm{Phe}^{23}-\mathrm{Phe}^{25}$ are involved in IGFBP binding by IGF-I or -II (Glemmons et al. 1992, Luthi et al. 1992, Bach et al. 1993, Francis et al. 1993, Dubaquie \& Lowman 1999). These residues are on the opposite face of IGF-I from mini-IGFBP-5, and their perturbations must therefore arise from interaction with the G-domain of IGFBP-2. As Phe ${ }^{23}-\mathrm{Phe}^{25}$ are essential for interaction with the type-1 IGF-I receptor (IGF-1R) (Cascieri et al. 1988, Bayne et al. 1990, Sakano et al. 1991, Perdue et al. 1994), our results imply that the C-domain of IGFBP-2 has a crucial role in blocking the interaction of IGF-I and -II with the IGF-1R. This would account for the relative inability of mini-IGFBP-5, which lacks the G-domain, to completely inhibit IGF-IR-dependent IGF actions (Kalus et al. 1998). In addition, $\mathrm{Glu}^{46}$ and $\mathrm{Cys}^{48}$ $\mathrm{Arg}^{50}$ are perturbed in both IGF-I and -II (Fig. 5A). Again, these are not part of the mini-IGFBP-5 interaction surface of IGF-I and are therefore candidates for interaction with the C-domain of IGFBP-2. Mutations in the $\mathrm{Cys}^{48}-\mathrm{Arg}^{50}$ region, highlight these residues as important in IGFBP binding by IGF-I or -II (Clemmons et al. 1992, Luthi et al. 1992, Bach et al. 1993, Francis et al. 1993, Dubaquie \& Lowman 1999). Interestingly, this region overlaps the IGF-II/mannose 6-phosphate receptor binding surface (Sakano et al. 1991). These results are consistent with recent findings for the $\mathrm{C}$-domain of IGFBP-6 (Headey et al. 2004b), which interacts with similar regions of IGF-II, and in particular $\mathrm{Phe}^{48}$ and $\mathrm{Arg}^{49}$. Given the proximity of $\mathrm{Cys}^{48}-\mathrm{Arg}^{50}$ to $\mathrm{Cys}^{52}$ Glu $^{58}$ of IGF-II, which contains five corresponding IGF-I residues in contact with mini-IGFBP-5, it is possible that the region around residue 50 represents a point of close contact between the $\mathrm{N}$ - and C-domains of the IGFBPs bound to IGF-I or -II.

Leu ${ }^{14}$ and Gln $^{15}$ (IGF-I numbering) are perturbed in both IGF-I and -II upon IGFBP-2 binding, even though they are not part of the contact surface in the mini-IGFBP-5-IGF-I crystal structure. Headey et al. (2004b) found that the $\operatorname{Gln}^{18}$ in IGF-II (equivalent to Gln ${ }^{15}$ in IGF-I) was perturbed by interaction with the G-domain of IGFBP-6. A further two residues, Gly ${ }^{19}$ and $\mathrm{Asp}^{20}$ of IGF-I and Gly ${ }^{22}$ and $\mathrm{Asp}^{23}$ of IGF-II, are perturbed in the presence of IGFBP-2 (Fig. 5A), even though they are not within $4 \AA$ of mini-IGFBP-5 in the structure of Zesławski et al. (2001). Nor are these residues of IGF-II affected upon interaction with the $\mathrm{C}$-domain of IGFBP-6 in solution (Headey et al. 2004b), although the preceding residue in IGF-II, Cys ${ }^{21}$, was broadened. These residues are located in a reverse turn in both IGF-I and -II, and it seems likely that their chemical shift perturbations arise from a local conformational change associated with residues in the helix before the turn interacting with the $\mathrm{N}$-domain, or with those after the turn interacting with the $\mathrm{G}$-domain. Mutation of these residues to alanine did not alter binding to IGFBP-1 or IGFBP-3 (Dubaquie \& Lowman 1999) which suggests that this is a perturbation specific to IGFBP-2. For Gly ${ }^{19}$ in IGF-I at least, we can conclude that its significant shift in the presence of full-length IGFBP-2 arises from interactions with the G-domain as it does not shift in the presence of the $\mathrm{N}$-domain alone.

$\mathrm{Gly}^{42}$ in IGF-I (Gly ${ }^{41}$ in IGF-II), which is slightly shifted in both IGF-I and -II, is on the opposite face of IGF-I from the mini-IGFBP-5 binding surface and was not affected by interaction with the $\mathrm{C}$-domain of IGFBP-6 (Headey et al. 2004b). Again, its slight shift probably reflects a small local conformational change. In IGF-II, Val ${ }^{35}$ undergoes a clear shift. This residue is located in the IGF-II C-domain, which is not thought to interact with IGFBPs, although $\mathrm{Val}^{35} \mathrm{Ala}$ IGF-I has a slightly lower affinity for IGFBP-1 (Dubaquie \& Lowman 1999). Also, both $\mathrm{Arg}^{36}$ and $\mathrm{Arg}^{37}$ of IGF-I were slightly perturbed upon binding to IGFBP-1 (Jansson et al. 1998) and their combined mutation to Ala reduced binding affinity to a moderate extent.

In summary, we have obtained good-quality spectra of the complexes of IGF-I and -II with IGFBP-2 and identified residues involved in the binding interfaces. Our results correlate well with those of Zesławski $e t$ al. (2001) on the interaction of mini IGFBP-5 with IGF-I but we have identified other residues not seen in the 
mini-IGFBP-5 study. Some of these coincide with regions identified by mutational analysis (e.g. $\mathrm{Cys}^{48}$ $\mathrm{Arg}^{50}$ of IGF-I) as having a role in IGFBP binding, and can therefore most likely be attributed to interaction with the IGFBP-2 C-domain (e.g. Phe ${ }^{23}-\mathrm{Phe}^{25}$ of IGF-I). Others, such as Gly ${ }^{19}-\mathrm{Asp}^{20}$, are likely to be perturbed as a result of local conformational changes. Our results also correlate well with those of Headey et al. (2004b), who mapped the IGF-II surface involved in binding the C-domain of IGFBP-6. Further definition of the IGF:IGFBP interaction surfaces will come with the use of saturation transfer methods (Takahashi et al. 2000, Nakanishi et al. 2002) coupled with stronger magnetic fields and cryogenically cooled probes to provide enhanced spectral sensitivity. Nonetheless, a consistent picture of the IGFBP $\mathrm{N}$-domain and C-domain binding surfaces of IGF-I and -II is already emerging from these studies, giving us a better understanding of the molecular basis for IGFBP modulation of IGF actions.

\section{Acknowledgements}

We are indebted to: Dr Guang Zhu of The Hong Kong University of Science and Technology for running the three-dimensional TROSY-NOESY at $750 \mathrm{MHz}$; Jennifer Sabo of the Walter and Eliza Hall Institute for assistance with spectral analysis; Chunxiao Wang of the Walter and Eliza Hall Institute for advice on IGF-I assignments and assistance with figures; Mrs C. Senn, Bresatec Ltd, Thebarton, South Australia, for assistance with the fermentations; Dr Leon Bach for helpful comments on the manuscript.

\section{Funding}

Financial support for part of this work was received from the CRC for Tissue Growth and Repair. F E C was the recipient of an Australian Postgraduate Research Award. The authors declare that there is no conflict of interest that would prejudice the impartiality of this scientific work.

\section{References}

Bach LA, Hsieh S, Sakano K, Fujiwara H, Perdue JF \& Rechler MM 1993 Binding of mutants of human insulin-like growth factor II to insulin-like growth factor binding proteins 1-6. Fournal of Biological Chemistry 268 9246-9254.

Bach LA, Hsieh S, Brown AL, Rechler MM 1994 Recombinant human insulin-like growth factor (IGF)-binding protein-6 inhibits IGF-II-induced differentiation of L6A1 myoblasts. Endocrinology $1352168-2176$.

Bagley CJ, May BL, Szabo L, McNamara PJ, Ross M, Francis GL, Ballard FJ \& Wallace JC 1989 A key functional role for the insulin-like growth factor $1 \mathrm{~N}$-terminal pentapeptide. Biochemical Fournal $259665-671$
Bartels C, Xia TH, Billeter P, Güntert P \& Wüthrich K 1995 The program XEASY for computer-supported NMR spectral-analysis of biological macromolecules. Fournal of Biomolecular NMR 6 1-10.

Bayne ML, Applebaum J, Chicchi GG, Hayes NS, Green BG \& Cascieri MA 1988 Structural analogs of human insulin-like growth factor I with reduced affinity for serum binding proteins and the type 2 insulin-like growth factor receptor. Fournal of Biological Chemistry 263 6233-6239.

Bayne ML, Applebaum J, Chicchi GG, Miller RE \& Cascieri MA 1990 The roles of tyrosines 24, 31, and 60 in the high affinity binding of insulin-like growth factor-I to the type 1 insulin-like growth factor receptor. Fournal of Biological Chemistry $\mathbf{2 6 5}$ $15648-15652$.

Bourner MJ, Busby WH Jr, Siegel NR, Krivi GG, McCusker RH \& Clemmons DR 1992 Cloning and sequence determination of bovine insulin-like growth factor binding protein-2 (IGFBP-2): comparison of its structural and functional properties with IGFBP-1. Fournal of Cellular Biochemistry 48, 215-226.

Carrick FE, Forbes BE \& Wallace JC 2001 BIAcore analysis of bovine insulin-like growth factor (IGF)-binding protein-2 identifies major IGF binding site determinants in both the amino- and carboxyl-terminal domains. Fournal of Biological Chemistry 276 27120-27128.

Carrick FE, Wallace JC \& Forbes BE 2002 The interaction of insulin-like growth factors (IGFs) with insulin-like growth factor binding proteins (IGFBPs): a review. Letters in Protein Science 8 147-153.

Cascieri MA, Saperstein R, Haves NS, Green BG, Chicchi GG, Applebaum J \& Bayne ML 1988 Serum half-life and biological activity of mutants of human insulin-like growth factor I which do not bind to serum binding proteins. Endocrinology 123 373-381.

Clemmons DR 2001 Use of mutagenesis to probe IGF-binding protein structure/function relationships. Endocrinology Reviews 22 800-817.

Clemmons DR, Dehoff ML, Busby WH, Bayne ML \& Cascieri MA 1992 Competition for binding to insulin-like growth factor (IGF) binding protein-2, 3, 4, and 5 by the IGFs and IGF analogs. Endocrinology 131 890-895.

Cooke RM, Harvey TS \& Campbell ID 1991 Solution structure of human insulin-like growth factor 1: a nuclear magnetic resonance and restrained molecular dynamics study. Biochemistry $\mathbf{3 0}$ 5484-5491

Denley A, Wallace JC, Cosgrove LJ, Forbes BE 2003 The insulin receptor isoform exon 11- (IR-A) in cancer and other diseases: a review. Hormone and Metabolic Research 35 778-785.

De Vroede MA, Rechler MM, Nissley SP, Joshi S, Burke GT \& Katsoyannis PG 1985 Hybrid molecules containing the B-domain of insulin-like growth factor I are recognized by carrier proteins of the growth factor. PNAS 82 3010-3014.

Ding W, Huang X, Yang X, Dunn JJ, Luft BJ, Koide S \& Lawson CL 2000 Structural identification of a key protective B-cell epitope in Lyme disease antigen OspA. Fournal of Molecular Biology $3021153-1164$.

Dubaquie Y \& Lowman HB 1999 Total alanine-scanning mutagenesis of insulin-like growth factor I (IGF-I) identifies differential binding epitopes for IGFBP-1 and IGFBP-3. Biochemistry 38 6386-6396.

Fernández C \& Wider G 2003 TROSY in NMR studies of the structure and function of large biological macromolecules. Current Opinion in Structural Biology 13 570-580.

Firth SM \& Baxter RC. 2002 Cellular actions of the insulin-like growth factor binding proteins. Endocrinology Reviewes 23 824-854.

Francis GL, Aplin SE, Milner SJ, McNeil KA, Ballard FJ \& Wallace JC 1993 Insulin-like growth factor (IGF)-II binding to IGF-binding proteins and IGF receptors is modified by deletion of the N-terminal hexapeptide or substitution of arginine for glutamate-6 in IGF-II. Biochemical fournal 293 713-719. 
Frystyk J 2004 Free insulin-like growth factors - measurements and relationships to growth hormone secretion and glucose homeostasis. Growth Hormone and IGF Research 14 337-375.

Headey SJ, Keizer DW, Yao S, Kanthiridis P, Bach LA \& Norton RS $2004 a$ C-terminal domain of insulin-like growth factor binding protein-6: structure and interaction with insulin-like growth factor-II. Molecular Endocrinology 18 2740-2750.

Headey SJ, Keizer DW, Yao S, Wallace JC, Bach LA \& Norton RS $2004 b$ Binding site for the C-domain of insulin-like growth factor (IGF) binding protein-6 on IGF-II; implications for inhibition of IGF actions. FEBS Letters 568 19-22.

Hua QX \& Weiss MA 1991 Comparative 2D NMR studies of human insulin and des-pentapeptide insulin: sequential resonance assignment and implications for protein dynamics and receptor recognition. Biochemistry 30 5505-5515.

Huang X, Yang X, Luft BJ \& Koide S 1998 NMR identification of epitopes of Lyme disease antigen OspA to monoclonal antibodies. Fournal of Molecular Biology 281 61-67.

Jansson M, Andersson G, Uhlen M, Nilsson B \& Kordel J 1998 The insulin-like growth factor (IGF)-binding protein 1 binding epitope on IGF-I probed by heteronuclear NMR spectroscopy and mutational analysis. Fournal of Biological Chemistry $\mathbf{2 7 3}$ 24701-24707.

Kalus W, Zweckstetter M, Renner C, Sanchez Y, Georgescu J, Grol M, Demuth D, Schumacher R, Dony C, Lang K \& Holak TA 1998 Structure of the IGF-binding domain of the insulin-like growth factor-binding protein-5 (IGFBP-5): implications for IGF and IGF-I receptor interactions. EMBO fournal 17 6558-6572.

King R, Wells JR, Krieg P, Snoswell M, Brazier J, Bagley CJ, Wallace JC, Ballard FJ, Ross M \& Francis GL 1992 Production and characterization of recombinant insulin-like growth factor-I (IGF-I) and potent analogues of IGF-I, with Gly or Arg substituted for Glu3, following their expression in Escherichia coli as fusion proteins. Fournal of Molecular Endocrinology 8 29-41.

Kline AD \& Justice RM Jr. 1990 Complete sequence-specific ${ }^{1} \mathrm{H}$ NMR assignments for human insulin. Biochemistry 29 2906-2913.

Koradi R, Billeter M \& Wüthrich K 1996 MOLMOL: a program for display and analysis of macromolecular structures. Fournal of Molecular Graphics 14 51-55.

Laajoki LG, Le Breton E, Shooter GK, Wallace JC, Francis GL, Carver JA \& Keniry MA 1997 Secondary structure determination of ${ }^{15} \mathrm{~N}$-labelled human Long-[Arg-3]-insulin-like growth factor 1 by multidimensional NMR spectroscopy. FEBS Letters $\mathbf{4 2 0}$ 97-102.

Laajoki LG, Francis GL, Wallace JC, Carver JA \& Keniry MA 2000 Solution structure and backbone dynamics of long-[Arg(3)] insulin-like growth factor-I. Fournal of Biological Chemistry 275 10009-10015.

Lian LY \& Roberts GCK 1993 Effects of chemical exchange on NMR spectra. In NMR of Macromolecules. A Practical Approach, pp 153-182. Ed. GGK Roberts. Oxford: IRL Press at Oxford University Press.

Lien S, Milner SJ, Graham LD, Wallace JC \& Francis GL 2001 Linkers for improved cleavage of fusion proteins with an engineered $\alpha$-lytic protease. Biotechnology and Bioengineering 74 335-343.

Luthi C, Roth BV \& Humbel RE 1992 Mutants of human insulin-like growth factor II (IGF II). Expression and characterization of truncated IGF II and of two naturally occurring variants. European Fournal of Biochemistry 205 483-490.

Magee BA, Shooter GK, Wallace JC \& Francis GL 1999 Insulin-like growth factor I and its binding proteins: a study of the binding interface using B-domain analogues. Biochemistry 38 15863-15870.

Nakanishi T, Miyazawa M, Sakakura M, Terasawa H, Takahashi H \& Shimada I 2002 Determination of the interface of a large protein complex by transferred cross-saturation measurements. Fournal of Molecular Biology 318 245-249.
Oh Y, Muller HL, Lee DY, Fielder PJ \& Rosenfeld RG 1993 Characterization of the affinities of insulin-like growth factor (IGF)-binding proteins 1-4 for IGF-I, IGF-II, IGF-I/insulin hybrid, and IGF-I analogs. Endocrinology 132 1337-1344.

Paisley AN \& Trainer PJ 2003 Medical treatment in acromegaly. Current Opinion in Pharmacology 3 672-677.

Perdue JF, Bach LA, Hashimoto R, Sakano K, Fujita-Yamaguchi Y, Fujiwara H \& Rechler MM 1994 Structural determinants for the binding of insulin-like growth factor-2 to IGF and insulin receptors and IGF binding proteins. In The Insulin-like Growth Factors and their Regulatory Proteins, pp. 67-76. Eds RC Baxter, PD Gluckman \& RG Rosenfeld. Amsterdam: Elsevier Science.

Pervushin K, Riek R, Wider G \& Wüthrich K 1997 Attenuated $T_{2}$ relaxation by mutual cancellation of dipole-dipole coupling and chemical shift anisotropy indicates an avenue to NMR structures of very large biological macromolecules in solution. PNAS 94 $12366-12371$.

Pollak MN, Schernhammer ES \& Hankinson SE 2004 Insulin-like growth factors and neoplasia. Nature Reviews Cancer 4 505-518.

Sakano K, Enjoh T, Numata F, Fujiwara H, Marumoto Y, Higashihashi N, Sato Y, Perdue JF \& Fujita-Yamaguchi Y 1991 The design, expression, and characterization of human insulin-like growth factor II (IGF-II) mutants specific for either the IGF-II/cation-independent mannose 6-phosphate receptor or IGF-I receptor. Fournal of Biological Chemistry 266 20626-20635.

Sato A, Nishimura S, Ohkubo T, Kyogoku Y, Koyama S, Kobayashi M, Yasuda T \& Kobayashi Y $1992{ }^{1} \mathrm{H}-\mathrm{NMR}$ assignment and secondary structure of human insulin-like growth factor-I (IGF-I) in solution. Fournal of Biochemistry (Tokyo) 111 $529-536$

Sato A, Nishimura S, Ohkubo T, Kyogoku Y, Koyama S, Kobayashi M, Yasuda T \& Kobayashi Y 1993 Three-dimensional structure of human insulin-like growth factor-I (IGF-I) determined by ${ }^{1} \mathrm{H}-\mathrm{NMR}$ and distance geometry. International Journal of Peptide and Protein Research $41433-440$.

Sato A, Koyama S, Yamada H, Suzuki S, Tamura K, Kobayashi M, Niwa M, Yasuda T, Kyogoku Y \& Kobayashi Y 2000

Three-dimensional solution structure of a disulfide bond isomer of the human insulin-like growth factor-I. Fournal of Peptide Research $\mathbf{5 6}$ 218-230.

Schaffer ML, Deshayes K, Nakamura G, Sidhu S \& Skelton NJ 2003 Complex with a phage display-derived peptide provides insight into the function of insulin-like growth factor I. Biochemistry $429324-9334$.

Sklenar V, Piotto M, Leppik R \& Saudek V 1993 Gradient-tailored water suppression for $\mathrm{H}-1-\mathrm{N}-15$ HSQC experiments optimized to retain full sensitivity. Fournal of Magnetic Resonance Series A 102 241-245.

Takahashi H, Nakanishi T, Kami K, Arata Y \& Shimada I 2000 A novel NMR method for determining the interfaces of large protein-protein complexes. Nature Structure Biolology 7 220-223.

Terasawa H, Kohda D, Hatanaka H, Nagata K, Higashihashi N, Fujiwara H, Sakano K \& Inagaki F 1994 Solution structure of human insulin-like growth factor II; recognition sites for receptors and binding proteins. EMBO fournal 13 5590-5597.

Torres AM, Forbes BE, Aplin SE, Wallace JC, Francis GL \& Norton RS 1995 Solution structure of human insulin-like growth factor II. Relationship to receptor and binding protein interactions. Fournal of Molecular Biology 248 385-401.

Vajdos FF, Ultsch M, Schaffer ML, Deshayes KD, Liu J, Skelton NJ \& de Vos AM 2001 Crystal structure of human insulin-like growth factor-1: detergent binding inhibits binding protein interactions. Biochemistry $4011022-11029$.

Wishart DS, Bigam CG, Yao J, Abildgaard F, Dyson HJ, Oldfield E, Markley JL \& Sykes BD $1995{ }^{1} \mathrm{H},{ }^{13} \mathrm{C}$ and ${ }^{15} \mathrm{~N}$ chemical shift referencing in biomolecular NMR. Fournal of Biomolecular NMR 6 135-140. 
Zesławski W, Beisel HG, Kamionka M, Kalus W, Engh RA, Huber R, Lang K \& Holak TA 2001 The interaction of insulin-like growth factor-I with the N-terminal domain of IGFBP-5. EMBO Fournal $203638-3644$.

Zhu G, Kong X, Yan X \& Sze K 1998 Sensitivity enhancement of transverse relaxation-optimized spectroscopy. Angewandte Chemie International Edition 37 2859-2861.
Zhu G, Kong X, \& Sze K 1999 Gradient and sensitivity enhancement of transverse relaxation-optimized spectroscopy with water flip-back. Fournal of Biomolecular NMR 13 77-81.

Received 29 November 2004

Accepted 23 February 2005 